\title{
Impairment of follicular development by intra-ovarian infusion of gonadotrophin-releasing hormone antiserum in prepubertal pigs
}

\author{
M. L. Patton*, K. L. Esbenshade $†$ and W. L. Flowers \\ Department of Animal Science, North Carolina State University, Raleigh, NC 27695-7621, USA
}

\begin{abstract}
Summary. Antiserum against gonadotrophin-releasing hormone (GnRH) was infused into one ovary in 4 prepubertal gilts and control porcine serum was infused into one ovary in 4 other gilts. Ovaries were infused for $156 \mathrm{~h}$, after which infused and noninfused ovaries were removed surgically and processed for histology. Infusion of GnRH antibodies did not alter $(P>0 \cdot 10)$ concentrations of luteinizing hormone (LH), follicle-stimulating hormone (FSH) or oestradiol-17 $\beta$, and GnRH titres in peripheral circulation were low, averaging 1:15. Weights of ovaries not infused were similar $(P>0.10)$ between treatment groups. There were fewer $(P<0.05)$ follicles $>0.5 \mathrm{~mm}$ in diameter in the ovaries infused with GnRH antiserum than in the others, but there were no differences $(P>0 \cdot 10)$ between treatment groups in the number of follicles $<0.5 \mathrm{~mm}$ in diameter. Infusion of $\mathrm{GnRH}$ antibodies increased $(P<0.05)$ the incidence of atresia in follicles with $>4$ layers of granulosa cells compared with the other treatment groups. These results provide evidence that a peptide binding to the GnRH antibodies is involved directly in ovarian follicular development.
\end{abstract}

Keywords: GnRH antiserum; follicular development; ovary; pig

\section{Introduction}

Gilts actively immunized against gonadotrophin-releasing hormone ( $\mathrm{GnRH}$ ) became acyclic and concentrations of luteinizing hormone $(\mathrm{LH})$, follicle-stimulating hormone (FSH) and ovarian steroids declined to nondetectable levels (Esbenshade \& Britt, 1985). Ovarian and uterine weights in immunized animals were reduced, the ovaries contained few antral follicles, and a high percentage of follicles with $>4$ layers of granulosa cells were atretic (Esbenshade, 1987; Traywick \& Esbenshade, 1988). Several approaches, none of which has been successful, have been employed to induce follicular development in these acyclic pigs. Gilts, actively immunized against GnRH, did not respond to a single injection or multiple injections of pregnant mares' serum gonadotrophin (PMSG) and intravenous injections of lyophilized pituitary extracts (Esbenshade, 1987). Attempts to induce follicular development were unsuccessful when a $\mathrm{GnRH}$ agonist, which did not cross react with the GnRH antibodies, was administered every other hour for 72 or $144 \mathrm{~h}$ (Traywick \& Esbenshade, 1988).

In attempts to initiate follicular development in gilts actively immunized against $\mathrm{GnRH}$, the immunoneutralization of hypothalamic GnRH was considered to be the cause of reproductive failure. However, evidence is accumulating that GnRH may have a direct action on pig ovaries and, in particular, on porcine granulosa cells. Massicotte et al. (1980) reported that a GnRH agonist inhibited FSH-stimulated, cyclic AMP accumulation in porcine granulosa cells. Similarly, Ledwitz-

*Present address: Center for the Reproduction of Endangered Species, San Diego, CA, USA.

$\dagger$ Reprint requests. 
Rigby (1990) demonstrated that a GnRH agonist depressed the secretion of progesterone by porcine granulosa cells in response to LH if present for at least $48 \mathrm{~h}$. These data and our inability to initiate folliculogenesis in immunized females with replacement therapy raise the possibility that immunization of pigs against GnRH may have a direct ovarian effect, interfering with ovarian compounds that may be acting as autocrine or paracrine regulators of folliculogenesis. To test this hypothesis, an antibody to $\mathrm{GnRH}$ was infused into ovarian interstitial tissue of prepubertal gilts for $156 \mathrm{~h}$ and the effects of this treatment on folliculogenesis were noted.

\section{Materials and Methods}

Animals and experimental protocol. Eight prepubertal gilts, $169 \pm 2$ (mean \pm s.e.) days of age were fitted nonsurgically with indwelling anterior vena cava cannulae on Day 0 . The cannulae were inserted through a 12-gauge needle and secured to the animal with elastic tape. On Day 1, a catheter was placed into the interstitial tissue of one ovary of each gilt and the gilts were assigned randomly to be infused with either $\mathrm{GnRH}$ antisera or control sera at $3 \mathrm{ml} / \mathrm{h}$ for $156 \mathrm{~h}$. On Day 7, the infusion was terminated and bilateral ovariectomies were performed. Four animals, 2 from each treatment group, were treated as replicate 1 . The other 4 animals were treated as replicate 2 and their infusion started 7 days after that in replicate 1 .

Blood sampling. Blood samples were collected every $6 \mathrm{~h}$ beginning at 12:00 $\mathrm{h}$ on Day 0 and concluding at $06: 00 \mathrm{~h}$ on Day 7. Blood samples were allowed to clot at $4^{\circ} \mathrm{C}$ and serum was collected by decanting the supernatant following centrifugation at $1700 \mathrm{~g}$ for $30 \mathrm{~min}$. Serum was stored at $-20^{\circ} \mathrm{C}$ until assayed for $\mathrm{LH}, \mathrm{FSH}$, and oestradiol-17 $\beta$. The $\mathrm{GnRH}$ antibody titre was measured in the last sample collected from each pig.

Ovarian catheter. Prior to surgery, double-walled catheters were prepared by threading a $1.22 \mathrm{~m}$ length of polyethylene tubing (Becton Dickinson \& Co., Parsippany, NJ, USA; PE-90; i.d. $0.86 \mathrm{~mm} \times$ o.d. $1.27 \mathrm{~mm}$ ) through a larger diameter tubing (PE-190; i.d. $1.19 \mathrm{~mm}$, o.d. $1.70 \mathrm{~mm})$. A short length $(5.08 \mathrm{~cm})$ of the smaller tubing was left exposed and was sealed with heat and silastic glue. A $3 \mathrm{~cm}$ section preceding the sealed end was perforated with a 22-gauge needle and the patency was confirmed by infusing deionized water. At the closed end of the tubing, and adjacent to the perforated section, another $1.27 \mathrm{~cm}$ piece of the larger tubing was slipped over the catheter and glued in place. This small piece was used to anchor the catheter to the ovary. On Day 1, a catheter was placed into one ovary of each gilt. Under general anaesthesia, an ovary was located and exteriorized through a midventral incision. A 16-gauge needle was then inserted through the side axis of the ovary and the double-walled catheter was inserted through the needle. The needle was then removed, leaving the catheter in the ovary. The catheter was secured to the ovary with 00 silk, fastened to the broad ligament with 2 sutures spaced at $7 \mathrm{~cm}$ and exteriorized through the paralumbar fossa.

Preparation and delivery of infusion sera. GnRH immunoserum used for ovarian infusion was collected previously from pigs immunized against GnRH and then lyophilized. The lyophilized antiserum was resuspended in deionized water, and antibody titre to GnRH was determined by serial dilutions of the sera as described by Esbenshade \& Britt (1985). The titre, expressed as the dilution that bound $50 \%$ of the ${ }^{125} \mathrm{I}-\mathrm{GnRH}$, was assessed to be 1:19000. The serum was further diluted with saline $(0.9 \% \mathrm{NaCl})$ to a dilution that contained an antibody titre of $1: 333$. Normal porcine serum from ovariectomized animals was diluted in saline to a similar degree and used as control serum. A Harvard Apparatus Infusion/Withdrawal Pump (Harvard Apparatus, Millis, MA, USA) was used to deliver $3 \mathrm{ml} / \mathrm{h}$.

Processing of ovaries. Ovaries were removed and trimmed of excess tissue. Noninfused ovaries were weighed, but infused ovaries could not be weighed because they had adhered to the surrounding tissue. Both ovaries were fixed in Bouin's solution for $12 \mathrm{~h}$, rinsed in $50 \%$ ethanol $(\mathrm{v} / \mathrm{v})$ and stored in $70 \%$ ethanol until processed. Ovaries were embedded in paraffin, sectioned serially at $10 \mu \mathrm{m}$ and every 50th section was mounted and stained with haematoxylin for histological examination. Follicular development was assessed by counting follicles which contained an oocyte. Follicles were divided into 4 classes: class I contained $<4$ layers of granulosa cells, class II had 4-8 layers of granulosa cells, class III had a diameter of $<0.5 \mathrm{~mm}$ and class IV were those with a diameter of $>0.5 \mathrm{~mm}$. Classes I and II were preantral follicles and classes III and IV were antral. Follicles were further assessed as to their state of health. They were judged atretic if the section containing the oocyte had $>5$ pycnotic bodies. Because of a high incidence of membrane breakdown and dislocation of granulosa cells from the basement membrane, class IV follicles were counted, but not assessed for incidence of atresia.

Hormone analysis and antibody titres. Serum concentrations of oestradiol-17 13 were quantified by previously reported and validated radioimmunoassays (Cox et al., 1987). Recovery of radiolabelled oestradiol following extraction averaged $88 \%$. Average assay sensitivity was $2 \mathrm{pg} / \mathrm{ml}$ and the intra- and interassay coefficients of variation were 14.2 and $16.1 \%$, respectively. Serum LH concentrations were quantified by radioimmunoassay (Stevenson et al., 1981; Armstrong et al., 1987) with porcine LH (LER-783-6) used as the standard and radioiodinated antigen, and antipLH (GDN 566) as the antibody. Average sensitivity of the LH assays, determined at $90 \%$ of the total binding, was $0.3 \mathrm{ng} / \mathrm{ml}$. Intra- and interassay coefficients of variation were 14.5 and $16.5 \%$, respectively. Serum FSH was quantified 
by radioimmunoassay procedures using anti-pFSH (USDA-10-07P), pFSH (USDA-FSH-PPI) as the radioiodinated antigen, and pFSH (USDA-pFSH-B-1) as the standard (Guthrie \& Bolt, 1983 as modified by Esbenshade \& Britt, 1985). Average assay sensitivity was $14.5 \mathrm{ng} / \mathrm{ml}$. Intra- and interassay coefficients of variation were 15.1 and $14.6 \%$, respectively. GnRH antibody titre was determined in serum at dilutions of 1:20 and 1:200.

Statistical analysis. Analysis of variance (ANOVA) using the general linear model (GLM) procedure of the statistical analysis system (SAS; 1985) was conducted to determine differences between treatments of serum concentrations of FSH, LH and oestradiol. The model for each hormone included treatment, pig-within-treatment, hour and the interaction between hour and treatment. Effect of treatment was tested using the pig-within-treatment mean square as the error term.

Differences in ovarian weight of noninfused ovaries were tested by Student's $t$ test. The number of follicles in each class and the incidence of atresia was tested by ANOVA in a $2 \times 2$ factorial design. The main effects were noninfused or infused ovaries and infusion with GnRH antiserum or control serum.

\section{Results}

\section{Hormone analysis and antibody titres}

Serum collected at the end of the infusion period from gilts infused with immune serum had antibody titres against GnRH ranging from 1:1 to $1: 35$, with an average of $1: 15$. The GnRH titre in animals receiving normal porcine serum was nondetectable. Serum concentrations of $\mathrm{LH}$, FSH and oestradiol did not differ $(P>0.10)$ between groups and averaged $0.55 \pm 0.05 \mathrm{ng} / \mathrm{ml}$, $34.24 \pm 1.96 \mathrm{ng} / \mathrm{ml}$ and $15.05 \pm 1.92 \mathrm{pg} / \mathrm{ml}$, respectively (Table 1 ).

Table 1. Concentrations of luteinizing hormone (LH), follicle-stimulating hormone (FSH) and oestradiol-17 $\beta$ (E2) in blood samples taken every $6 \mathrm{~h}$ while gilts were infused into one ovary with gonadotrophin-releasing hormone (GnRH) antibodies or control serum

\begin{tabular}{lcc}
\hline & \multicolumn{2}{c}{ Treatment } \\
\cline { 2 - 3 } Hormone & GnRH antiserum & Control serum \\
\hline LH $(\mathrm{ng} / \mathrm{ml})$ & $0.66 \pm 0.07$ & $0.53 \pm 0.03$ \\
FSH $(\mathrm{ng} / \mathrm{ml})$ & $35.3 \pm 2.1$ & $33.2 \pm 1.9$ \\
E2 $(\mathrm{pg} / \mathrm{ml})$ & $14.9 \pm 2.0$ & $15.2 \pm 1.9$ \\
\hline
\end{tabular}

Values are means \pm s.e.

\section{Ovarian weight}

The weight of ovaries not infused with serum for gilts treated with GnRH antiserum and with control serum was, respectively, $3.7 \pm 0.9$ and $4.4 \pm 1.6 \mathrm{~g}(P>0 \cdot 10)$.

\section{Ovarian histology}

The total number of class I follicles and incidence of atresia were similar $(P>0 \cdot 10)$ for all ovaries without regard to infusion status or serum being infused (Table 2). The number of class II follicles was similar $(P>0 \cdot 10)$ in all treatment groups. The percentage of class II follicles that were classified as atretic in ovaries infused with $\mathrm{GnRH}$ antiserum $(70 \%)$ was greater $(P<0.05)$ than those infused with porcine serum $(50 \%)$, or those not infused from either group $(50 \%$ and $44 \%$ from control and GnRH-antiserum groups, respectively). The numbers of class III follicles were similar $(P>0 \cdot 10)$, but the percentage that were atretic was higher in the ovaries infused with 
GnRH antiserum than in ovaries not infused. The total number of follicles in class IV was lower $(P<0.05)$ in ovaries infused with GnRH antiserum than in noninfused ovaries of both groups or in ovaries infused with control serum.

Table 2. Total number of follicles and percentage of follicles that were atretic in gilts infused into one ovary with gonadotrophin-releasing hormone $(\mathrm{GnRH})$ antibodies or control serum

\begin{tabular}{|c|c|c|c|c|c|c|c|c|}
\hline \multirow[b]{3}{*}{ Treatment } & \multicolumn{8}{|c|}{ Class of follicle* } \\
\hline & \multicolumn{2}{|r|}{ I } & \multicolumn{2}{|c|}{ II } & \multicolumn{2}{|c|}{ III } & \multicolumn{2}{|c|}{ IV } \\
\hline & Number & $\%$ atretic & Number & $\%$ atretic & Number & $\%$ atretic & Number & $\%$ atretic \\
\hline \multicolumn{9}{|l|}{ Control serum } \\
\hline Not infused & $221 \pm 13$ & $25 \pm 2$ & $173 \pm 17$ & $50 \pm 2^{\mathrm{c}}$ & $36 \pm 5$ & $75 \pm 4^{d}$ & $19 \pm 3^{c}$ & ND \\
\hline Infused & $248 \pm 15$ & $18 \pm 1$ & $192 \pm 12$ & $50 \pm 3^{c}$ & $48 \pm 3$ & $77 \pm 1^{\text {d,e }}$ & $16 \pm 2^{c}$ & ND \\
\hline \multicolumn{9}{|c|}{ GnRH antiserum } \\
\hline Not infused & $238 \pm 11$ & $22 \pm 6$ & $156 \pm 20$ & $44 \pm 3^{c}$ & $46 \pm 9$ & $63 \pm 2^{c}$ & $20 \pm 3^{c}$ & ND \\
\hline Infused & $253 \pm 18$ & $23 \pm 1$ & $145 \pm 22$ & $70 \pm 3^{d}$ & $27 \pm 4$ & $87 \pm 4^{e}$ & $5 \pm 2^{d}$ & ND \\
\hline
\end{tabular}

Values are means \pm s.e. of 4 observations. ${ }^{*}$ Class I: $<4$ layers of granulosa cells; Class II: 4-8 layers of granulosa cells; Class III: $<0.5 \mathrm{~mm}$ antral; Class IV: $>0.5 \mathrm{~mm}$ antral.

$\mathrm{ND}=$ not determined.

${ }^{\mathrm{c}, \mathrm{d}, \mathrm{e}}$ Values within a column with different superscripts $\operatorname{differ}(P<0 \cdot 05)$.

\section{Discussion}

Confirmation that the GnRH antibodies were infused into the ovaries of the treated gilts was obtained during ovariectomies when the cannulae were ascertained to be in place and from the determination of low GnRH antibody titres in these pigs. A reduction in circulating concentrations of gonadotrophins was observed in gilts actively or passively immunized against GnRH with titre levels > 1:400 (Esbenshade et al., 1986; Traywick \& Esbenshade, 1988), but not when they were $<$ 1:200 (K. L. Esbenshade, unpublished data). The low amount of GnRH antiserum given in the present experiment did not have a systemic effect, as revealed by several findings. There were no differences in the concentrations of serum LH, FSH or oestradiol between pigs infused with GnRH antiserum and pigs infused with control serum. Average weight and number of surface follicles on noninfused ovaries from gilts treated with GnRH antiserum or control serum were similar. Histological observations revealed no differences in the number of follicles or incidence of atresia in ovaries not infused (Table 2).

Intra-ovarian infusion of $\mathrm{GnRH}$ antiserum reduced the number of follicles $>0.5 \mathrm{~mm}$ in diameter and induced atresia in a high percentage of follicles with $>4$ layers of granulosa cells. These results are similar to those reported previously where ovaries taken from gilts actively immunized against GnRH contained few antral follicles and most ( $>98 \%$ ) of the follicles with $>4$ layers of granulosa cells were atretic (Esbenshade, 1987; Traywick \& Esbenshade, 1988). Infusion of control serum in the present study did not alter the number of follicles or the incidence of atresia. The findings observed here together with those reported previously suggest that the GnRH antibodies are binding an antigen in the ovary and interfering with folliculogenesis in pigs. The antigen is involved in the early stages of follicular development as disruption of follicular development occurs in preantral follicles with 4 or more layers of granulosa cells.

A GnRH-like peptide(s) has been postulated to exist in the ovaries of a range of species (Aten et al., 1986; Ireland et al., 1988). Specific receptors that bind GnRH and GnRH agonist have also been shown to exist in a range of species (Clayton et al., 1979; Jones et al., 1980; Latouche et al., 
1989) and the actions of these compounds on the ovary have been reported to be both stimulatory and inhibitory. Although Brown \& Reeves (1983), using a radioreceptor assay of ovarian homogenates, reported that porcine ovaries lacked GnRH receptors, several lines of evidence indicate that a physiological action of a GnRH-like compound at the level of the ovary is a component of folliculogenesis in pigs. Massicotte et al. (1980) demonstrated that the addition of a GnRH agonist to porcine granulosa cells inhibited FSH-stimulated cyclic AMP accumulation and progesterone secretion and Ledwitz-Rigby (1990) reported that a GnRH agonist depressed basal and LH-stimulated progesterone secretion by porcine granulosa cells of antral follicles $>3 \mathrm{~mm}$ in diameter. Jackson et al. (1989) detected the presence of a compound in the ovary of pigs with immunological properties of GnRH that is associated with small atretic follicles.

Data from pigs (Ledwitz-Rigby \& Dement-Liebenow, 1989) and humans (Latouche et al., 1989) suggest that not all follicles have receptors for GnRH-like compounds and that the presence of a GnRH-like compound may be associated with pycnotic nuclei and atresia (P. DementLiebenow \& F. Ledwitz-Rigby as cited in Ledwitz-Rigby, 1990). In the present study, localized intra-ovarian infusion of GnRH antibodies was associated with an increase in the incidence of atresia in preantral follicles, indicating that the peptide binding to the antibodies would be located in follicles at this stage of development.

The antibody against GnRH used in the present study was polyclonal. Cross reactivity tests exhibited $<1 \%$ cross reactivity of the GnRH antiserum with $2 \mathrm{GnRH}$ analogues, D-(Ala ${ }^{6}$, des-Gly- $\mathrm{NH}_{2}{ }^{10}$ ) (Traywick \& Esbenshade, 1987) and des-Gly ${ }^{10}$, [D-Phe ${ }^{6}$ ]-LH-RH ethylamide (K. L. Esbenshade, unpublished data). However, a potent GnRH antagonist, [D-pGlu ${ }^{1}$, D-Phe ${ }^{2}$, D-Trp ${ }^{3,6}$ ]-LH-RH (Rivier \& Vale, 1978), exhibited $30 \%$ cross reactivity with this antibody (K. L. Esbenshade, unpublished data). This finding leads to the speculation that a GnRH antagonist-like protein may exist in the porcine ovary and that this molecule may play a role in sustaining follicular development. In support of the idea that there may be gonadal antagonists of GnRH is the finding of Arimura \& Turkelson (1984) who reported rat testicular GnRH-like immunoreactive substances that demonstrated moderate GnRH agonist and strong GnRH antagonist characteristics when introduced to pituitary fragments. More recently, Ledwitz-Rigby (1989) demonstrated that a GnRH antagonist, [AC-D-Phe ${ }^{1}, \mathrm{D}-\mathrm{p}$ Cl-Phe ${ }^{2}$,DTRP 3,6]-GnRH, enhanced basal and LHstimulated progesterone secretion in porcine follicles of $1-5 \mathrm{~mm}$ in diameter and that this action was independent of the ability of charcoal-treated follicular fluid to enhance FSH-stimulated progesterone secretion. Aten \& Behrman (1989a, b) identified a GnRH-binding inhibitor in the bovine ovary that evoked antigonadotrophic responses in luteal and granulosa cells similar to GnRH agonists. Whereas the effects of the GnRH agonist could be blocked with a GnRH antagonist, the GnRH antagonist was not effective against the binding inhibitor. They identified the binding inhibitor as histone $\mathrm{H} 2 \mathrm{~A}$, but its physiological significance or species specificity is unknown. Taken together these results suggest that porcine granulosa cells respond to GnRH agonists and antagonists in an opposite manner and that GnRH-like molecules in porcine ovaries may have a role in controlling follicular development.

In summary, infusion of an antiserum against GnRH into pig ovaries induced atresia in preantral and antral follicles without exerting a systemic effect. These observations are consistent with the hypothesis that $\mathrm{GnRH}$-like compounds are present in the porcine ovary acting as paracrine or autocrine regulators of folliculogenesis in pigs.

The use of trade names in this publication does not imply endorsement by the North Carolina ARS of the products named, or criticism of similar ones not mentioned.

Thanks are given to D. J. Bolt, USDA Hormone Program for donating purified porcine $\mathrm{LH}$ and FSH and porcine FSH antisera; G. D. Niswender for supplying antisera to LH; L. E. Reichert, Jr, for providing purified porcine LH (LER 786-3); N. R. Mason, Eli Lilly Laboratories, for supplying the oestrogen antisera; and to T. Steffel and $\mathrm{S}$. Wagner for care of the animals. 


\section{References}

Armstrong, J.D., Kraeling, R.R. \& Britt, J.H. (1987) Effects of naloxone or transient weaning on secretion of $\mathbf{L H}$ and prolactin in lactating sows. $J$. Reprod. Fert. 83, 301-308.

Arimura, A. \& Turkelson, C.M. (1984) LHRH-like substance in rat testis. Ann. N.Y. Acad. Sci. 438, 390-393.

Aten, R.F. \& Behrman, H.R. (1989a) A gonadotropinreleasing hormone-binding inhibitor from bovine ovaries. Purification and identification as histone H2A. J. Biol. Chem. 264, 11065-11071.

Aten, R.F. \& Behrman, H.R. (1989b) Antigonadotropic effects of the bovine ovarian gonadotropin-releasing hormone-binding inhibitor/histone $\mathrm{H} 2 \mathrm{~A}$ in rat luteal and granulosal cells. J. biol. Chem. 264, 11072-1 1075.

Aten, R.F., Williams, A.T., Behrman, H.R. \& Wolin, D.L. (1986) Ovarian gonadotropin-releasing hormonelike protein(s): demonstration and characterization. Endocrinology 118, 961-967.

Brown, J.L. \& Reeves, J.J. (1983) Absence of specific luteinizing hormone receptors in ovine, bovine and porcine ovaries. Biol. Reprod. 29, 1179-1182.

Clayton, R.N., Harwood, J.P. \& Catt, K.T. (1979) GnRH analogue binds to luteal cells and inhibits progesterone production. Nature, Lond. 282, 90-92.

Esbenshade, K.L. (1987) Ovarian responses to pregnant mares serum gonadotropin and porcine pituitary extract in gilts actively immunized against gonadotropin releasing hormone. J. Anim. Sci. 65, $1768-1774$.

Esbenshade, K.L. \& Britt, J.H. (1985) Active immunization of gilts against gonadotropin-releasing hormone: effects on secretion of gonadotropins, reproductive function, and responses to agonists of gonadotropinreleasing hormone. Biol. Reprod. 33, 569-577.

Esbenshade, K.L., Vogel, M.J. \& Traywick, G.B. (1986) Clearance rate of luteinizing hormone and follicle stimulating hormone from peripheral circulation in the pig. J. Anim. Sci. 62, 1649-1653.

Guthrie, H.D. \& Bolt, D.J. (1983) Changes in plasma oestrogen, luteinizing hormone, follicle stimulating hormone and 13,14-dihydro-15-keto prostaglandin F2 $\alpha$ during blockage of luteolysis in pigs after human chorionic gonadotropin treatment. J. Anim. Sci. 57, 993-1000.

Ireland, J.J., Aten, R.F. \& Behrman, H.R. (1988) GnRH. like proteins in cows: concentrations during corpora lutea development and selective localization in granulosa cells. Biol. Reprod. 38, 544-550.
Jackson, K.I., Meleka, M., Chen, C.L. \& Bauer, F.W. (1989) Immunoreactive GnRH in the pig ovary. Fed. Proc. Abstr. 3720.

Jones, P.B.C., Conn, P.M., Marian, J. \& Hsueh, A.J.W. (1980) Binding of gonadotropin-releasing hormone agonist to ovarian granulosa cells. Life Sci. 27, 2125-2132.

Latouche, J., Crumeyrolle-Arias, M., Jordan, D., Kopp, N., Augendre-Ferrante, B., Cedard, L. \& Haour, F. (1989) GnRH receptors in human granulosa cells: anatomical localization and characterization by autoradiographic study. Endocrinology 125, 1739-1741.

Ledwitz-Rigby, F. (1989) A comparison of the actions of stimulatory follicular fluid and gonadotropinreleasing hormone analogs on progesterone secretion by porcine granulosa cells. Biol. Reprod. 41, 604-609.

Ledwitz-Rigby, F. (1990) Gonadotropin-releasing hormone inhibition of $\mathrm{LH}$ stimulated progesterone secretion by porcine granulosa cells in vitro. Dom. Anim. Endocr. 7, 265-272.

Ledwitz-Rigby, F. \& Dement-Liebenow, P. (1989) Direct actions of gonadotropin-releasing hormone and visualization of its receptors on porcine ovaries. In Growth Factors and the Ovary, pp. 279-284. Ed. A. N. Hirshfield. Plenum Press, USA.

Massicotte, J., Veilleux, R., Lavoie, M. \& Labrie, F. (1980) An LHRH agonist inhibits FSH-induced cyclic AMP accumulation and steroidogenesis in porcine granulosa cells in culture. Biochem. Biophys. Res. Commun. 94, 1362-1366.

Rivier, J.E. \& Vale, W.W. (1978) [D-pGlu ${ }^{1}$, D-Phe ${ }^{2}$, D-Trp ${ }^{3,6}$-LRFF. A potent luteinizing hormone releasing factor antagonist in vitro and inhibitor of ovulation in the rat. Life Sci. 23, 869-876.

SAS Institute Inc. (1985) SAS User's Guide: Statistics, 5 th edn. SAS Institute, Cary, NC, USA.

Stevenson, J.S., Cox, N.M. \& Britt, J.H. (1981) Role of the ovary in controlling LH, FSH, and prolactin secretion during and after lactation in pigs. Biol. Reprod. 24, 341-353.

Traywick, G.B. \& Esbenshade, K.L. (1988) Pulsatile administration of gonadotropin-releasing hormone agonist to gilts actively immunized against gonadotropin-releasing hormone. J. Anim. Sci. 66, 2209-2215. 